\title{
Eastern Pacific migration strategies of pink-footed shearwaters Ardenna creatopus: implications for fisheries interactions and international conservation
}

\author{
Jonathan J. Felis ${ }^{1, *}$, Josh Adams ${ }^{1}$, Peter J. Hodum ${ }^{2}$, Ryan D. Carle ${ }^{2}$, \\ Valentina Colodro ${ }^{2}$
}

${ }^{1}$ U.S. Geological Survey, Western Ecological Research Center, Santa Cruz, California, 95060, USA

${ }^{2}$ Oikonos Ecosystem Knowledge, Valparaíso, Región de Valparaíso, 2380486, Chile

\begin{abstract}
The pink-footed shearwater Ardenna creatopus has a breeding range restricted to 3 central-Chilean islands and travels north in the eastern Pacific Ocean during the non-breeding period. Despite its Vulnerable IUCN status, the locations and relative importance of core nonbreeding areas and migratory pathways of the species are not well understood. During 5 years between 2006 and 2015, we tracked the movements of 42 after-hatch-year pink-footed shearwaters in the non-breeding season using satellite tags. Tracked shearwaters exhibited 2 postbreeding-season migration strategies: $28 \%$ of individuals traveled 1600-2500 km north from their colonies to spend the entire non-breeding season off Peru, and $72 \%$ traveled $8000-11000 \mathrm{~km}$ north to waters off western North America (Baja California, Mexico, to southernmost Canada). Individuals that traveled to North America stopped in Peruvian waters on each leg of the migration, making this a migratory bottleneck. Core non-breeding-season areas included continental shelf and slope waters off Trujillo to Lima (Peru), central Baja California (Mexico), southern to central California (USA), and central Oregon (USA) to southern Vancouver Island (Canada). Of 12 national exclusive economic zones (EEZs) encountered north of their breeding range, birds primarily utilized the USA, Peru and Mexico, and to a lesser degree Chile, Canada, and Ecuador. Bycatch in fisheries was recently identified as a significant at-sea threat to pink-footed shearwaters, and we found evidence of pink-footed shearwater bycatch in 6 EEZs encountered by tracked birds, although quantification of bycatch magnitude is variable and not all fisheries have been studied.
\end{abstract}

KEY WORDS: Satellite tracking - Fishery bycatch - California Current - Humboldt current · Non-breeding $\cdot$ Seabird $\cdot$ Home range

\section{INTRODUCTION}

Delineating migratory pathways and at-sea distributions of marine birds during their non-breeding periods is important for identifying high-priority conservation and management areas (Shaffer et al. 2006, Guilford et al. 2009, Adams et al. 2012). Despite rapid advances in the study of marine wildlife made possible by new bio-logging technologies, basic infor-

*Corresponding author: jfelis@usgs.gov

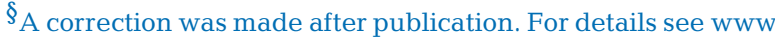
int-res.com/abstracts/esr/v39/c_p269-282/ This corrected version: August 19, 2019 mation - including locations of migratory corridors, stop-over sites, and non-breeding habitat at sea - is poorly established, anecdotal, or unknown (Block et al. 2011). In addition, long-distance migratory species that cross international boundaries or utilize international waters present complex conservation challenges which cannot be addressed without detailed and accurate location data (Nevins et al. 2009, Yorio 2009, Croxall et al. 2012).

( $)$ Peter J. Hodum, Ryan D. Carle, Valentina Colidoro, and, outside of the USA, the US Government 2019. Open Access under Creative Commons by Attribution Licence. Use, distribution and reproduction are unrestricted. Authors and original publication must be credited.

Publisher: Inter-Research · www.int-res.com 
Many shearwater species (Family Procellariidae) breeding in temperate regions undertake longdistance, trans-equatorial migrations between the breeding and non-breeding periods to take advantage of seasonally productive waters. Tracking studies have described the migratory movements of several of these species (Shaffer et al. 2006, González-Solís et al. 2007, Guilford et al. 2009, Hedd et al. 2012, Carey et al. 2014). For example, postbreeding adult sooty shearwaters Ardenna grisea from New Zealand travel to the North Pacific during the boreal summer, with round-trip migratory distances exceeding $40000 \mathrm{~km}$ (Shaffer et al. 2006). Such long-distance movements enable shearwaters to take advantage of multiple, widely dispersed oceanic resources, but also expose them to at-sea threats at an ocean-basin scale (Shaffer et al. 2006).

The pink-footed shearwater A. creatopus is known to breed only on the Chilean islands of the Juan Fernández Archipelago and Isla Mocha (Brooke 2004), with the majority nesting on Isla Mocha (Guicking et al. 2004). No reliable published world population estimate exists, though estimates from breeding colonies have consistently been <100000 breeding individuals (reviewed by Brooke 2004). Due to threats at breeding colonies (e.g. invasive species, habitat loss and degradation, and human harvest of chicks; Guicking et al. 1999, Hinojosa Saez \& Hodum 2007, Carle et al. 2016) and at-sea (primarily fisheries bycatch; Mangel et al. 2012, Suazo et al. 2014), this species is listed as endangered by Chile (Hinojosa Saez \& Hodum 2007), threatened by Canada (Environment Canada 2008), Vulnerable by the International Union for Conservation of Nature (IUCN; BirdLife International 2017), and is included in Annex 1 of the Agreement on the Conservation of Albatrosses and Petrels (ACAP 2015). Breeding pinkfooted shearwaters appear to forage exclusively in Chilean waters (Guicking et al. 2001, Carle et al. 2019). During the non-breeding period, pink-footed shearwaters migrate north from Chile to as far as the USA and Canada; however, the locations and relative importance of core non-breeding-season areas and migratory pathways at sea are not well understood.

Delineating migratory pathways and important non-breeding-season habitat is critical for assessing at-sea threats to pink-footed shearwaters, especially the risk of fisheries bycatch. During their migration between Chile and North America, birds have the potential to pass through the exclusive economic zones (EEZs) of all eastern Pacific nations as well as international waters, where they may overlap with many different fisheries. Mortality of pink-footed shearwaters from fisheries bycatch has been reported or documented in multiple countries, with the greatest bycatch currently believed to occur in Chile and Peru (estimates range from 500 to 1000s of birds killed each year in each country; Mangel et al. 2012, Suazo et al. 2014, Vega et al. 2018). There is extensive overlap and bycatch mortality of pink-footed shearwaters during the breeding season associated with Chilean purse-seine fleets targeting Peruvian anchoveta Engraulis ringens and common sardine Strangomera (Clupea) bentincki (Suazo et al. 2014, Vega et al. 2018, Carle et al. 2019). Because neither fisheries effort nor shearwater habitat-use has been comprehensively studied across their range at sea, it is unknown if estimated or documented bycatch rates are correlated with pink-footed shearwater use of any specific region, regional fishing effort, or some combination of both.

In this study, we tracked the non-breeding-season movements of pink-footed shearwaters during multiple years to describe timing and routes of migration, locate and assess relative importance of core nonbreeding residency areas, describe at-sea characteristics of important pink-footed shearwater nonbreeding-season habitat, and identify priority areas for at-sea conservation of pink-footed shearwaters during the non-breeding season. Based on at-sea survey data, we expected that pink-footed shearwaters would use waters from Peru to southern Canada in the non-breeding period. We also expected that tracked birds would primarily use continental shelf and slope waters, meaning that the majority of their time would be spent in national territorial, rather than international, waters.

\section{MATERIALS AND METHODS}

During 5 years between 2006 and 2015, we captured and tagged pink-footed shearwaters at breeding colonies in Chile (Isla Santa Clara in the Juan Fernández Archipelago [ $\mathrm{n}=5$ birds], Isla Mocha [ $\mathrm{n}=$ 25]), and at-sea off southern California ( $\mathrm{n}=12$; Table 1, Fig. 1). Tags deployed in Chile provided information on post-breeding-season migration, nonbreeding-season residency areas, and occasionally the return migration to Chilean breeding areas when tag retention/functionality was sufficient. Tags deployed off southern California provided additional information on North American non-breeding movements and habitat use, as well as return migration to Chile. In Chile, we captured birds by hand at night 
Table 1. Summary of pink-footed shearwater Ardenna creatopus satellite tagging effort, tracking time, cumulative distance tracked, and speed-distance-angle (SDA) filter results, 2006-2015. JFA: Juan Fernández Archipelago

\begin{tabular}{|lcccccc|}
\hline Year & Tagging location & $\mathrm{n}$ & $\begin{array}{c}\text { Duty cycle } \\
\text { (hours on:off) }\end{array}$ & $\begin{array}{c}\text { Mean days } \\
\text { tracked (range) }\end{array}$ & $\begin{array}{c}\text { Mean distance } \\
\text { (km) tracked (range) }\end{array}$ & $\begin{array}{c}\text { Mean \% of locations } \\
\text { retained fter SDA } \\
\text { filter (range) }\end{array}$ \\
\hline 2006 & Chile (JFA) & 5 & $10: 48$ & $47(12-95)$ & $5200(1664-10361)$ & $81.6(75.1-84.9)$ \\
2009 & California & 5 & $10: 48$ & $157(114-217)$ & $16038(11959-19345)$ & $83.7(78.3-88.5)$ \\
2011 & Chile (Isla Mocha) & 9 & $6: 8$ & $157(98-248)$ & $18775(8515-7926)$ & $81.1(62.2-91.8)$ \\
2013 & Chile (Isla Mocha) & 6 & $7: 36$ & $112(23-213)$ & $11075(6174-1023)$ & $75.3(64.5-82.0)$ \\
& California & 7 & $6: 8$ & $139(110-165)$ & $15786(8130-22770)$ & $88.0(86.2-89.5)$ \\
2015 & Chile (Isla Mocha) & 10 & $6: 8$ & $159(100-236)$ & $18964(9257-33003)$ & $86.9(84.7-89.7)$ \\
All years & & 42 & & $135(12-248)$ & $15280(1023-33003$ & $83.2(62.2-91.8)$ \\
\hline
\end{tabular}

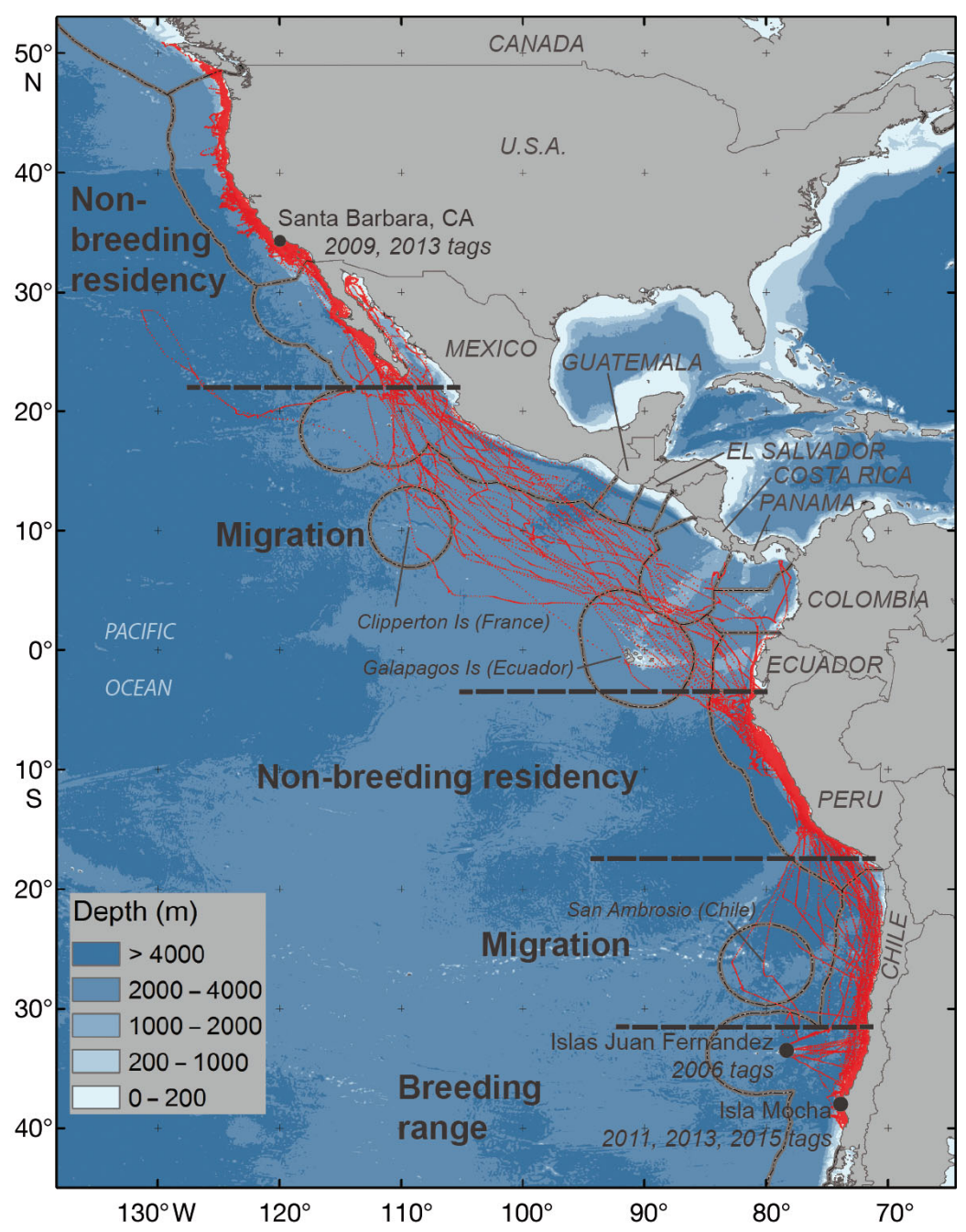

Fig. 1. Pink-footed shearwater Ardenna creatopus breeding- and nonbreeding-season residency areas, and migratory corridors of birds tracked from Chile and California ( $\mathrm{n}=42$ birds), 2006-2015. Interpolated tracking data are shown in red, and tagging sites and years are labeled. Thick black dashed lines indicate latitudinal breaks between different regions, as determined by speed (see Fig. 2). Boundaries of exclusive economic zones (EEZ) used by pink-footed shearwaters are also shown (thin black dashed lines with gray outline) when they returned to the colony late in the breeding season (March-April). Off southern California, we captured shearwaters at sea in the Santa Barbara Channel using a handheld spotlight and dip net from a small skiff at night early in the non-breeding season (May-June). All birds were confirmed to be of after-hatchyear age based on flight feather molt patterns. We attached satellite platform terminal transmitters (PTTs; potted solar PTT100 12g [Microwave Telemetry; 17g final mass; $<3 \%$ of mean pink-footed shearwater mass; Guicking et al. 2004]) to individuals' mid-dorsum using a suturetape-glue combination (MacLeod et al. 2008, Adams et al. 2012) and programmed PTTs to transmit at duty cycles designed to prolong battery life (Table 1).

Our objective was to track pink-footed shearwaters for as long as possible during their extended $(\sim 7 \mathrm{mo})$ non-breeding season, while minimizing the risk of tag effects. Therefore, we considered several available attachment techniques used on similar-sized shearwaters and alcids (e.g. glue, tape, and harness). Although waterproof tape has been used effectively with penguins to achieve relatively long (several months) device attachments (Wilson et al. 1997), penguins have comparatively short, robust feathers and dense dorsal plumage compared with shearwaters and alcids. Using tape and/or epoxy to attach similar sized PTTs to shearwaters, researchers have only been able to obtain tracking durations of 1 to $46 \mathrm{~d}$ (Klomp \& Schultz 2000, Söhle et al. 2000, Guicking et al. 2001, Einoder \& Goldsworthy 2005). 
Ristow et al. (2000) used teflon harnesses to track 4 post-breeding Cory's shearwaters Calonectris borealis for 3 to $6 \mathrm{mo}$, but these birds were not successfully relocated at the colony during the following season. Furthermore, modified leg-loop harnesses for northern fulmars Fulmarus glacialis caused nest abandonments and likely resulted in adult mortality (Mallory \& Gilbert 2008). Based on these results indicating relatively short-duration tape/glue attachments and concerns regarding harness techniques, we opted for non-surgical, external PTT attachments using previously established suture techniques for seabirds (Newman et al. 1999) modified for attachments to petrels (Macleod et al. 2008; J. Adams unpubl. data) and shearwaters (Adams et al. 2012). Recapture and removal of similar PTTs attached with the same methods to breeding Hawaiian petrels Pterodroma sandwichensis (J. Adams \& A. Raine unpubl. data) upon return to nesting sites after 2 to $4 \mathrm{wk}$ indicated expected wear and loss of some sutures, with no apparent abnormalities associated with remaining sutures. Because the pink-footed shearwaters studied herein were not associated with known burrows in the colony and we were tracking adults after they dispersed, similar to several other studies using our methods (Adams et al. 2012, Reid et al. 2014, Powers et al. 2017, Ronconi et al. 2018), we were unable to directly measure device effects on bird condition or behavior. Instead, we visually evaluated transmissions for changes in the tag's internal tilt counter (i.e. reduced motion), battery voltage, or locations associated with land that might indicate compromised bird condition, tag failure, or stranding, respectively.

We determined the geographic coordinates of individual birds using the Argos System (CLS America 2011) and archived data via the Satellite Tracking and Analysis Tool (STAT; Coyne \& Godley 2005). We used STAT to flag and manually correct 'mirror' locations, and we removed duplicate records (i.e. when Argos returned 2 records with the same time), retaining the record with the more accurate location class (LC) or greater number of satellite messages. To remove data points requiring unrealistic flight speeds and movement spikes, we removed LC-Z Argos data and filtered remaining data (LC-3 through LC-B) using a speed-distance-angle (SDA) filter in R (version 3.4.3, R Core Team 2017; sdafilter function in the argosfilter package; Freitas et al. 2008), specifying a $16.7 \mathrm{~m} \mathrm{~s}^{-1}$ speed threshold and default settings for distances and angles (Adams et al. 2012). Applying this type of filter to paired GPS-Argos avian tracking data has been shown to remove most locations with
$>21 \mathrm{~km}$ error (Douglas et al. 2012). We accounted for variable sampling frequencies by applying a continuous-time-correlated random walk (CRAWL) model to filtered tracking data ( $\mathrm{R}$ package crawl; Johnson et al. 2008). We predicted shearwater movement paths across the entire duration of each tag deployment and incorporated previously measured Argos location class error values from Douglas et al. (2012) into the model framework $(\mathrm{LC}-3=0.4 \mathrm{~km}, \mathrm{LC}-2=1.0 \mathrm{~km}$, $\mathrm{LC}-1=2.5 \mathrm{~km}, \mathrm{LC}-0=7.9 \mathrm{~km}, \mathrm{LC}-\mathrm{A}=4.8 \mathrm{~km}, \mathrm{LC}-\mathrm{B}=$ $10.0 \mathrm{~km})$. These error measurements from paired GPS-Argos animal-borne tags better represent the accuracy of each location class than those estimated by Argos (Le Boeuf et al. 2000, Costa et al. 2010, Witt et al. 2010, Douglas et al. 2012). Hourly locations were predicted from each shearwater's fitted model; these predicted locations were used in all subsequent analyses.

To define boundaries for non-breeding-season residency areas and migratory corridors, we calculated the mean distance traveled between successive predicted hourly locations for all birds in $1^{\circ}$ latitude bins throughout the geographic extent of the telemetry data (Fig. 1). Latitude bins with mean speeds less than the median of all bins were defined as residency areas, and those greater than the median were classified as migratory corridors where birds likely were transiting and interacting less with local habitat. We compared this result with the same classification method applied to SDA-filtered (un-interpolated) data to investigate if predicting movement paths across PTT off-duty periods had any effect. Waters south of $32^{\circ} \mathrm{S}$ were defined as breeding range because this latitude was found to be the northern extent of breeding season foraging trips of birds tracked from Chilean colonies (Guicking et al. 2001, Carle et al. 2019). For each individual, we determined the date of departure from, date of arrival into, and time spent within each non-breeding-season residency area and migratory corridor. For birds tagged in Chile, we calculated the proportion of individuals that ultimately reached and spent the majority of the non-breeding period within specific residency areas. If a bird remained off northern South America after initial postbreeding migration and its tag stopped transmitting, it was inferred to have used that region as an ultimate non-breeding residency area only if it remained past the latest observed departure among the birds that departed from South American to North American waters; otherwise, ultimate non-breeding residency area was considered unknown.

We calculated the 95\% (home range) and 50\% (core) contours of the kernel utilization distribution 
(UD; Worton 1989) within non-breeding residency areas to spatially describe non-breeding-season habitat use. CRAWL-predicted data for all individuals were pooled in each area, and UDs were calculated in R (kernelUD function in adehabitat package; Calenge 2006) with a smoothing factor (h) equal to the mean error of locations predicted during interpolation $(21.1 \mathrm{~km})$. We computed the volume intersection of these UDs with those created using only the SDA-filtered (un-interpolated) data to investigate if significant differences existed due to interpolation across PTT off-duty periods. The first 6 days of tracking data for shearwaters tagged at sea off California were removed to reduce the potential effect of tagging location bias on UD calculation. In addition to describing spatial hotspots within non-breedingseason residency areas, we compared the mean proportions of individuals' time spent over continental shelf ( $<200 \mathrm{~m}$ depth), slope (200-1000 m depth), and rise/abyssal waters (>1000 $\mathrm{m}$ depth) in the combined core use areas in each non-breeding-season residency area. Depth values were extracted at all predicted bird locations from ETOPO1 bathymetry (Amante \& Eakins 2009) using ArcGIS 10.3 (ESRI). Results are reported as mean \pm SD unless otherwise noted.

Finally, we calculated the percent of all tracking time (pooled for all individuals) spent in each EEZ where shearwaters traveled within the non-breeding range and summarized reported and documented pink-footed shearwater bycatch for fisheries in those EEZs from both peer-reviewed and gray literature.

\section{RESULTS}

In 5 different years, we tracked 42 pink-footed shearwaters for an average of $135 \pm 55 \mathrm{~d}$ (range $=$ 12-248 $d_{i}$ Table 1, Table S1 in the Supplement at www.int-res.com/articles/suppl/n039p269_supp.pdf). In total, $21 \%$ (9 of 42 ) of individual PTTs indicated that a voltage drop occurred at the end of the transmission period before transmissions ceased altogether, pointing to potential battery failure. No individual PTT records demonstrated final transmissions on land that would suggest stranding. Only 2 PTTs exhibited tilt sensor records indicative of anomalous inactivity before transmission ceased, both in 2006 when we recorded shorter duration transmission periods ( $47 \pm 34 \mathrm{~d}, \mathrm{n}=5$ birds) than in other study years (range of annual means 112-159 di Table 1, Table S1). These 2 birds were tracked for relatively short durations (PTT 64 379, 18 di PTT 64377, 12 d), and contributed little to the overall results. Although no formal effort was made to re-sight tagged individuals at colonies post-tracking, 1 individual pinkfooted shearwater (PTT 137990) that was tagged at Isla Mocha in 2015 was opportunistically recaptured within the same area of the colony in 2016, in good condition and without its transmitter (R. D. Carle pers. obs.).

Speed-distance-angle filtering retained $83.2 \pm$ $6.8 \%$ of original locations (Table 1, Table S2 in the Supplement). The percentage of original locations retained corresponded to location class quality (LC3: $97.5 \%$; LC-2: 96.5\%; LC-1: 92.6\%; LC-0: 78.6\%; LC-A: $75.8 \%$; LC-B: 70.2\%; Table S2). For the duration of each tag's lifetime, the average cumulative distance traveled by individuals was $15280 \pm 7462 \mathrm{~km}$ (range $=1023-33003 \mathrm{~km}$; Table 1, Table S1). Outside of the breeding range (north of $32^{\circ} \mathrm{S}$ ), average cumulative distance traveled was $13992 \pm 6895 \mathrm{~km}$ (range $=164-31271 \mathrm{~km}$; excluding 1 tag that ceased transmitting before departure from breeding waters; Table S1). Tagged pink-footed shearwaters ranged as far north as Vancouver Island, Canada $\left(51^{\circ} \mathrm{N}\right)$, during the non-breeding period (Fig. 1). The latitudinal boundaries of breeding-season waters, nonbreeding-season residency areas, and migratory corridors were well defined by rapid transitions in speed at specific latitudes (Fig. 2). Classifications of latitudinal boundaries using SDA-filtered data and CRAWLpredicted data were identical; we used CRAWLpredicted locations for subsequent analyses. We classified latitudinal bins with mean speeds $<7.8 \mathrm{~km}$ $\mathrm{h}^{-1}$ (187.2 $\mathrm{km} \mathrm{d}^{-1}$; the median value across all bins) as residency areas and all other bins as migratory corridors. Birds exhibited migratory transit speeds from central Chile to southern Peru $\left(32^{\circ}-17^{\circ} \mathrm{S}_{;} \sim 1600 \mathrm{~km}\right)$, and from northern Peru to southern Baja California, Mexico ( $4^{\circ} \mathrm{S}-23^{\circ} \mathrm{N}_{i} \sim 4300$ km; Fig. 2).

Shearwaters stopped over between southern and northern Peru $\left(17^{\circ}\right.$ and $4^{\circ} \mathrm{S}$, respectively) and either spent the entire non-breeding period there or continued northward to spend most of the non-breeding period off North America between southern Baja California, Mexico, and Vancouver Island, Canada $\left(22^{\circ}-51^{\circ} \mathrm{N}_{i}\right.$ Fig. 3). Most birds departing for North America from Peru left early in the post-breeding season; $72 \%$ (13 of 18 birds) left earlier than the midpoint day-of-year value (151) of the overall range (117-184; Fig. 3). If a bird's tag ceased transmitting while off Peru after Day 184, it was inferred to have spent the remainder of the non-breeding period there. Of the individuals tagged in Chile for which we could determine an ultimate non-breed- 


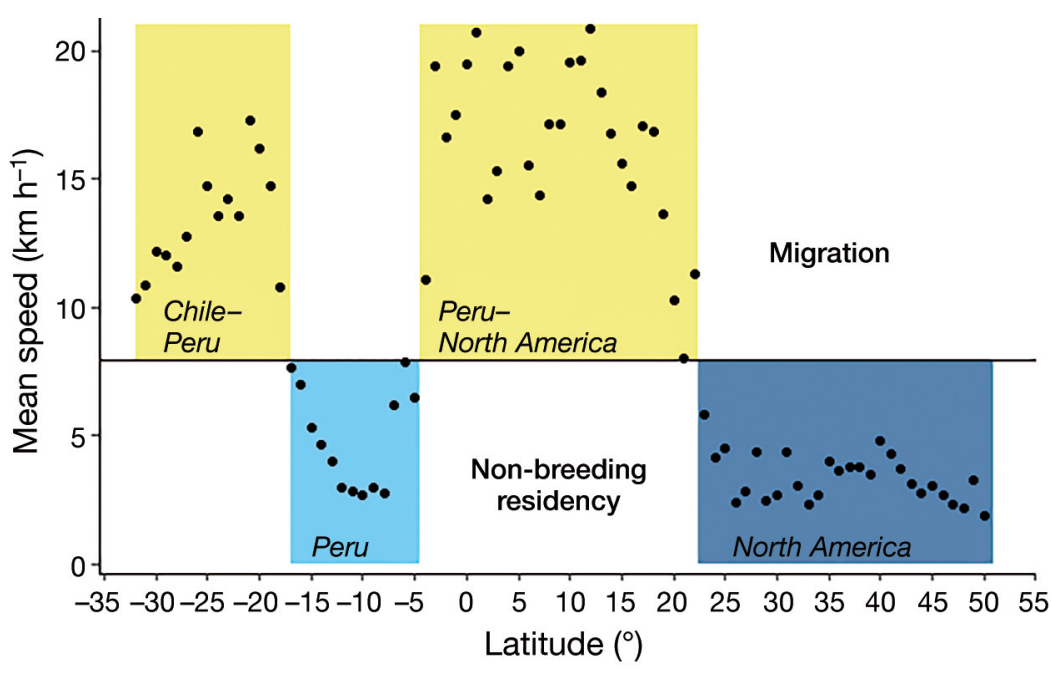

Fig. 2. Mean speed in $1^{\circ}$ latitude bins of tracked pink-footed shearwaters Ardenna creatopus across their non-breeding-season range $\left(32^{\circ} \mathrm{S}-51^{\circ} \mathrm{N}\right)$. Horizontal black line indicates median value used to determine migratory corridor (>median) vs. non-breeding residency $(<$ median) areas. Migratory corridors between Chilean breeding range and Peru, and between Peru and North America, are highlighted in yellow. Non-breeding residency areas off Peru and North America are highlighted in light and dark blue, respectively ing residency area (25 of 30 birds, all years combined), $28 \%$ spent the nonbreeding period off northern South America (2 birds confirmed from complete round-trip tracks, 5 inferred) and $72 \%$ traveled to waters off North America. Of the 5 birds for which we inferred Peru as an ultimate residency area, 4 birds' tags lasted for $\sim 2$ mo after our cutoff (Day 184) and 1 tag lasted for nearly 1 mo before transmission ceased (Fig. 3). Sample sizes were too small to assess inter-annual variation in non-breeding residency destination (Table 1).

Most post-breeding pink-footed shearwaters left the central Chilean breeding region between late April and early May and returned there between midOctober and late-November (Fig. 3). The timing of movements was consistent between individuals, with standard deviations of individual day-of-year values for arrival or departure into breeding and

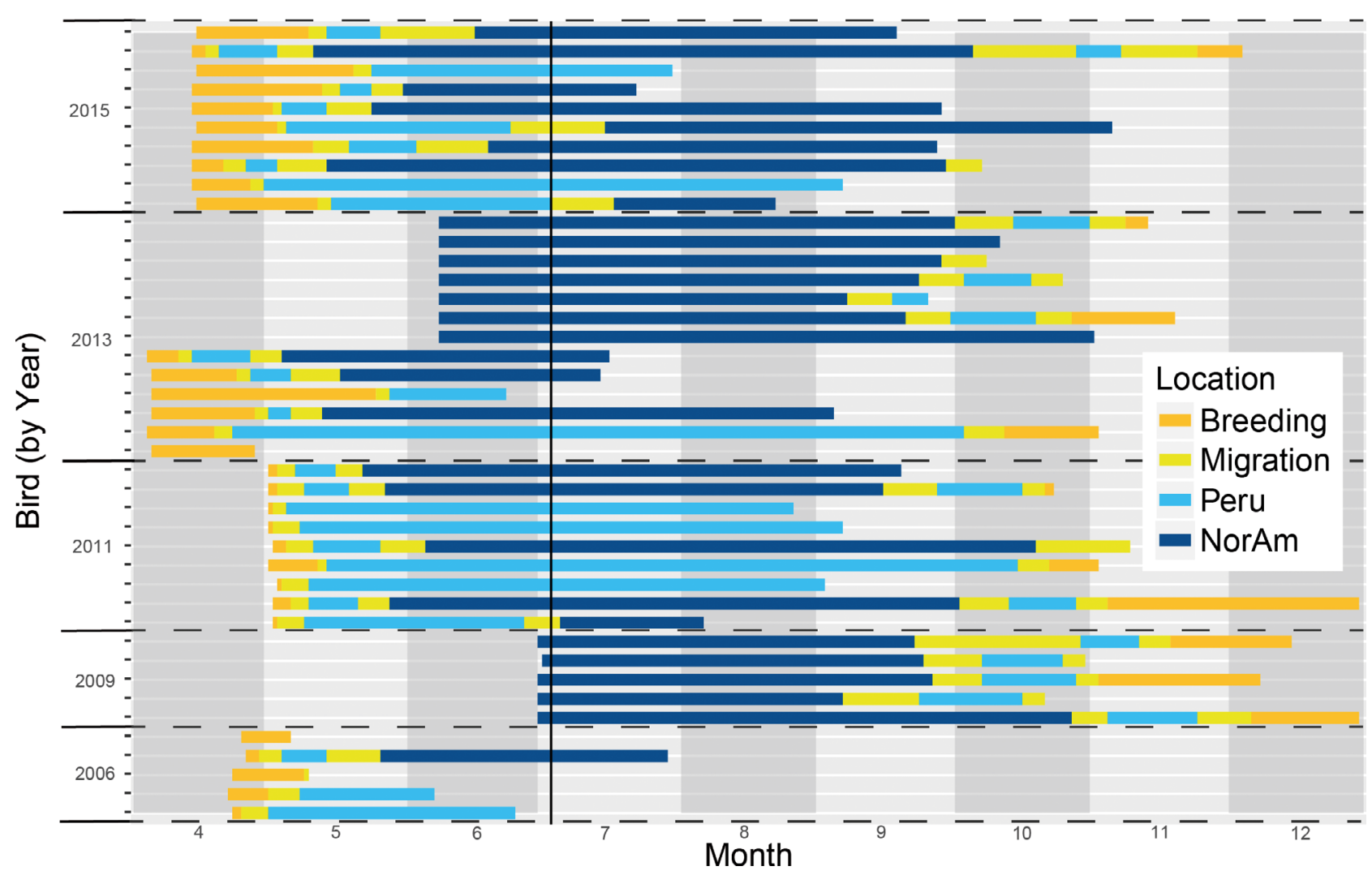

Fig. 3. Deployment plot of individual pink-footed shearwater Ardenna creatopus tracking data mapped to breeding $\left(<32^{\circ} \mathrm{S}\right.$ orange), migratory corridor (yellow), and non-breeding-season residency (blue) areas over the year (by day of year) for all tagged birds, 2006-2015. Light blue indicates Peru and dark blue North America (NorAm). Vertical black line indicates latest known day of the year that any individual tagged in Chile migrated north from Peru to North America 
non-breeding residency areas ranging from 9.6$22.5 \mathrm{~d}$. Birds spent $4.3 \pm 1.6 \mathrm{~d}$ (range $2-8$ ) during northward migration and $8.1 \pm 3.4 \mathrm{~d}$ (range 5-17) during southward migration traveling between the breeding region and southern Peru. Migrants ultimately bound for North America stopped off northern South America for $17.8 \pm 15.2$ d (northward; range 5-50 di late April-late May) and $17.3 \pm 3.8 \mathrm{~d}$ (southward; range 10-23 di late September-midNovember). Birds traveling to North America spent $10.8 \pm 4.7 \mathrm{~d}$ (northward; range 6-21 $\mathrm{d}_{i}$ ) and $14.2 \pm$ $7.9 \mathrm{~d}$ (southward; range 8-37 $\mathrm{d}_{i}$ ) migrating between northern Peru and Baja California, Mexico. Once off North America, most movements progressed northward throughout the non-breeding season to connect several high-use areas; individuals conducted more direct and unabbreviated southward movements through and out of this residency area during the return migration.

When traveling between the breeding region and southern Peru, pinkfooted shearwaters utilized coastal to pelagic waters up to $1100 \mathrm{~km}$ from shore (Fig. 1). While migrating between South and North America, birds typically traveled throughout a broad offshore region 400-1700 km from shore (Fig. 1). Although individual migration pathways were dispersed, most travel was direct between coastal Peru and the west coast of Baja California (Fig. 1). Exceptions included temporary entry into the Gulf of California (northbound only; 3 birds), and an extreme case of 1 individual approaching Baja California from the south after likely having become entrained in a series of northwestwardmoving hurricanes for 2 wk (hurricanes Andres and Blanca; National Hurricane Center 2018). This bird was displaced $1400 \mathrm{~km}$ offshore, over $1000 \mathrm{~km}$ farther than all other birds tracked at that latitude. (Fig. 1).

The volume intersections between SDA-filtered and CRAWL-predicted kernel UDs calculated in the North America and Peru non-breeding residency areas were high (89.1 and $92.7 \%$, respectively), therefore we used CRAWL-predicted outputs for subsequent analysis and interpretation. In the non-breeding residency area off Peru, the $50 \%$ UD contour indicated core-use areas from Trujillo to Lima (north-central Peru) and an overall home range extending north from southern Peru to southern Ecuador (Fig. 4). In North America, core-use areas included waters off central Baja California (Mexico), southern to central California (USA), and central Oregon (USA) to southern Vancouver Island (Canada; Fig. 4). In both residency areas, core use was located over continental shelf (mean individual time $[ \pm \mathrm{SE}] 58.8 \pm 5.2 \%$ in

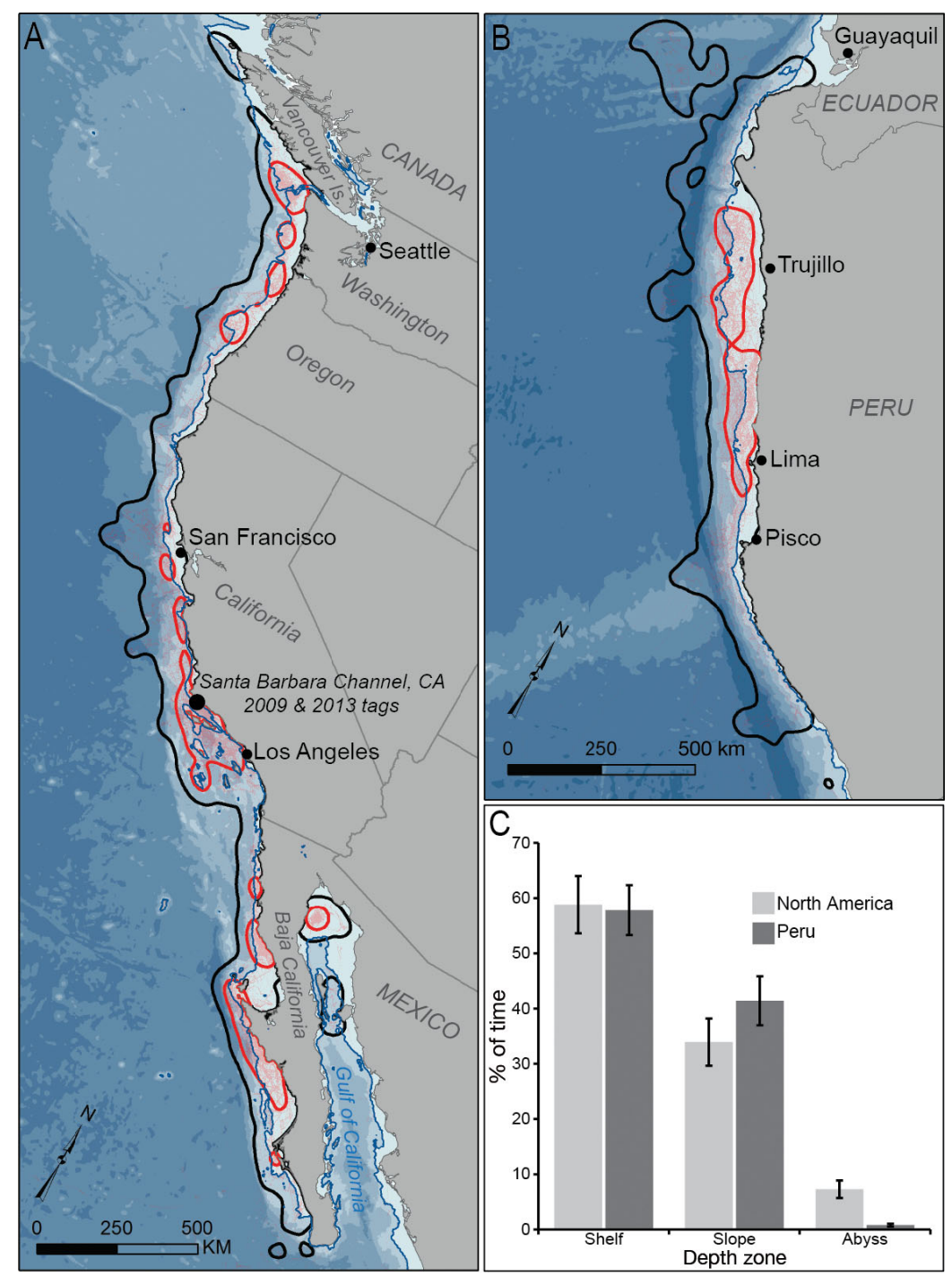

Fig. 4. Core (50\%, red outline) and home range (95\%, black outline) contours of kernel utilization distributions calculated for tagged pink-footed shearwaters Ardenna creatopus in non-breeding-season residency areas off (A) North America and (B) Peru. Continental shelf break (200 m isobath) is shown as blue line. $(C)$ Mean $( \pm$ SD) of percent individual time spent over continental shelf $(\leq 200 \mathrm{~m}$ depth), slope (201-1000 $\mathrm{m}$ depth), and rise/abyssal (>1000 m depth) waters in core use areas off Peru and North America 
North America, $57.8 \pm 4.5 \%$ in South America) and continental slope waters $(33.9 \pm 4.3 \%$ in North America, $41.4 \pm 4.4 \%$ in South America), with little coreuse time spent over abyssal waters (Fig. 4).

Pink-footed shearwaters visited 12 unique EEZs and international high seas. For all pooled tracking data collected north of breeding waters $\left(32^{\circ} \mathrm{S}\right)$, birds primarily utilized the EEZs of the USA. (34\% of total tracking time), Peru $(30 \%)$, and Mexico
$(24 \%)$, and to a lesser extent Chile $(4 \%)$, Canada and Ecuador (1-2\%), and various central American nations $(<1 \%$ combined; Costa Rica, Colombia, France [Clipperton Island], Panama, Guatemala, El Salvador; Table 2). We found literature reporting or documenting pink-footed shearwater bycatch from fisheries in 6 of those EEZs (USA, Mexico, Guatemala, Ecuador, Peru, Chile), and international waters (Table 2).

Table 2. Relative use of distinct exclusive economic zones (EEZ) by tracked pink-footed shearwaters Ardenna creatopus in the non-breeding period (i.e. all track locations north of $32^{\circ} \mathrm{S}$ ) and summary of fisheries with reported or documented pink-footed shearwater bycatch from peer-reviewed literature, gray literature, and personal communications with fisheries investigators (Enriqueta Velarde of Universidad Veracruzana, Mexico). Set: unique deployment of fishing gear; N/A: not available

\begin{tabular}{|c|c|c|c|c|c|}
\hline $\begin{array}{l}\text { National EEZ } \\
\text { (listed north } \\
\text { to south) }\end{array}$ & $\begin{array}{l}\% \text { total } \\
\text { pink-footed } \\
\text { shearwater } \\
\text { tracking time }\end{array}$ & $\begin{array}{l}\text { Fisheries with repo } \\
\text { Fishery type }^{\mathrm{a}}\end{array}$ & $\begin{array}{l}\text { rted or documented pir } \\
\text { Method }^{\mathrm{b}}\end{array}$ & $\begin{array}{l}\text {-footed shearwater bycatch } \\
\text { Magnitude (mortality) }\end{array}$ & Citation \\
\hline Canada & 1.6 & None identified & N/A & Unknown & N/A \\
\hline United States & 34.1 & Long line & $\begin{array}{l}\text { Trial fishery study } \\
\text { Observer program }\end{array}$ & $\begin{array}{c}1 \text { bird per } 33 \text { sets } \\
\text { Estimated 3.33-6.77 } \\
(95 \% \text { CI: } 0.8-14.1) \text { birds } \mathrm{yr}^{-1} \\
\text { from 2010-2016 } \\
\text { Estimated 0.48-2.35 } \\
\text { (95\% CI: } 0-7.8) \text { birds } \mathrm{yr}^{-1} \\
\text { from } 2010-2016\end{array}$ & $\begin{array}{l}\text { Gladics et al. (2017) } \\
\text { Jannot et al. (2018) }\end{array}$ \\
\hline Mexico & 23.7 & Purse seine & Observer program & Present & E. Velarde unpubl. data \\
\hline $\begin{array}{l}\text { France (Clipper- } \\
\text { ton Island) }\end{array}$ & 0.2 & None identified & N/A & Unknown & N/A \\
\hline Guatemala & $<0.1$ & Long line & Trial observer study & Present & Dávila Pérez et al. (2009) \\
\hline El Salvador & $<0.1$ & None identified & N/A & Unknown & N/A \\
\hline Costa Rica & 0.5 & None identified & N/A & Unknown & N/A \\
\hline Panama & 0.1 & None identified & N/A & Unknown & N/A \\
\hline Colombia & 0.3 & None identified & N/A & Unknown & N/A \\
\hline $\begin{array}{l}\text { Ecuador (incl. } \\
\text { Galapagos) }\end{array}$ & 1.2 & Demersal long line & Trial observer study & $\begin{array}{l}2 \text { birds per } 417 \text { sets } \\
\text { (capture rate; fate unknown) }\end{array}$ & Mangel (2012) \\
\hline Peru & 29.8 & Gill net & $\begin{array}{l}\text { Trial observer study } \\
\text { Trial fishery study }\end{array}$ & $\begin{array}{c}3 \text { birds per } 914 \text { sets; estimated } \\
500-1000 \text { birds } \mathrm{yr}^{-1} \\
3 \text { birds per } 729 \text { sets }\end{array}$ & $\begin{array}{l}\text { Mangel et al. (2012) } \\
\text { Bielli (2017) }\end{array}$ \\
\hline Chile & 4.2 & $\begin{array}{l}\text { Purse seine } \\
\text { Gillnet, long line, } \\
\text { purse seine } \\
\text { Trawl } \\
\text { Demersal long line }\end{array}$ & $\begin{array}{l}\text { Observer program } \\
\text { Trial fishery study } \\
\text { Fisher interviews } \\
\text { Trial fishery study } \\
\text { Fisher interviews }\end{array}$ & $\begin{array}{c}1510 \text { birds per } 1630 \text { sets } \\
\text { Present } \\
\text { Estimated } 911 \text { birds } \mathrm{yr}^{-1} \\
\text { (mostly gillnet) } \\
\text { Present } \\
\text { Present }\end{array}$ & $\begin{array}{c}\text { Vega et al. (2018) } \\
\text { Suazo et al. (2014) } \\
\text { Mangel et al. ((2012) } \\
\text { ATF (2013), } \\
\text { Suazo et al. (2014) } \\
\text { Mangel et al. (2012) }\end{array}$ \\
\hline $\begin{array}{l}\text { International } \\
\text { waters }\end{array}$ & 4.4 & Driftnet & $\begin{array}{l}\text { Observer program } \\
\text { Observer program }\end{array}$ & $\begin{array}{c}\text { Present } \\
\text { Estimated } 412 \text { birds } \text { yr }^{-1}\end{array}$ & $\begin{array}{l}\text { Johnson et al. (1993) } \\
\text { Ogi et al. (1993) }\end{array}$ \\
\hline 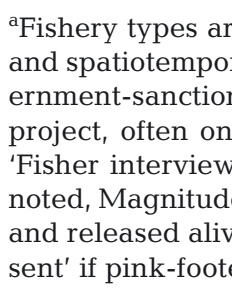 & $\begin{array}{l}\text { general and } \\
\text { ral fishing effor } \\
\text { ned, fleet-wide } \\
\text { a smaller scal } \\
\text { Is' is informatic } \\
\text { e indicates the } \\
\text { e. An annual n } \\
\text { ed shearwater }\end{array}$ & $\begin{array}{l}\text { yy represent small- } \\
\text { jithin a nation. Cons } \\
\text { ycatch observation } \\
\text { 'Trial fishery study' } \\
\text { on bycatch collecte } \\
\text { served number of bi } \\
\text { tality estimate is pre } \\
\text { atch was reported }\end{array}$ & $\begin{array}{l}\text { large-scale fisheries } \\
\text { t original sources fo } \\
\text { ogram. 'Trial obsery } \\
\text { research-oriented } \\
\text { from interviewing } f \\
\text { s killed per number } \\
\text { ented when it was p } \\
\text { documented but no }\end{array}$ & $\begin{array}{l}\text { a combination) that may vary } \\
\text { ecific fishery information; }{ }^{\prime} \mathrm{Ob} \\
\text { study' is an independent byca } \\
\text { aing effort to study bycatch a } \\
\text { ers in a particular fishery or } \mathrm{r} \\
\text { ets monitored. Additional birds } \\
\text { ided by the original source. } \mathrm{M} \\
\text { antification was provided in th }\end{array}$ & $\begin{array}{l}\text { y in vessel size, fleet size, } \\
\text { bserver program' is a gov- } \\
\text { atch observation research } \\
\text { Ind/or gear modifications. } \\
\text { region; 'Unless otherwise } \\
\text { s may have been captured } \\
\text { lagnitude is noted as 'pre- } \\
\text { le original study }\end{array}$ \\
\hline
\end{tabular}




\section{DISCUSSION}

In this study, we found that satellite-tracked pinkfooted shearwaters performed trans-equatorial migrations up to $\sim 11000 \mathrm{~km}$ from their breeding sites in Chile, with cumulative travel distances as great as $\sim 31000 \mathrm{~km}$ outside of the breeding range. During the non-breeding season, tagged shearwaters utilized continental shelf and slope habitats in distinct residency areas along the Pacific coasts of Peru and North America (primarily the USA and Baja California, Mexico), and birds traveled relatively rapidly through migratory corridors between these areas and breeding waters. The distinction between nonbreeding-season residency areas and migratory corridors was well-defined by rapid transitions in speed across relatively short distances at specific latitudes. Pink-footed shearwaters predominately used the waters of Peru, Mexico, and the USA in the nonbreeding period.

Individuals were generally consistent in timing and duration of migratory movements, and travel speeds were greatest in the migratory corridors we identified (Table 1, Figs. 1 \& 2). Standard deviations of individual day-of-year values for arrival or departure at breeding and non-breeding residency areas ranged from $\sim 1-3 w k$, indicating that most major pink-footed shearwater movements occur at similar times of year. Mean travel speeds were slower within the northern Chile migration corridor, suggesting some foraging or resting may occur there, compared with the migratory leg between Peru and Mexico spanning deep, offshore waters. Sooty shearwaters stop foraging and migrate rapidly across low latitude waters that have lower primary productivity (Shaffer et al. 2006). The migratory waters between Peru and Mexico over which pink-footed shearwaters rapidly traveled in this study could have lower productivity and/or not support desired prey, although we did not investigate that in this study. All tracked birds spent some portion of the non-breeding period off Peru, and the majority of tracked birds ultimately spent the non-breeding period off North America (Fig. 2, Table 1).

Distribution patterns documented in this study are consistent with nonbreeding distributions measured during ship and aerial at-sea surveys in the California Current (Briggs et al. 1987, Mason et al. 2007, Adams et al. 2014), which report similar aggregations regionally and with respect to bathymetry. Furthermore, the overall mean tracking duration among individual pink-footed shearwaters herein (135 \pm $55 \mathrm{~d}$ ) is similar to the mean durations reported using the same attachment technique applied to spectacled petrels Procellaria conspicillata $\left(130 \pm 53 \mathrm{~d}_{i}\right.$ Reid et al. 2014), sooty shearwaters (108 $\pm 26 \mathrm{~d}$; Adams et al. 2012), and greater shearwaters Puffinus gravis (159 \pm $70 \mathrm{~d}$ i Ronconi et al. 2018). In this study, we observed normal behavior and/or tag voltage drops when tag transmissions ceased. Although we do not know how these transmitters may have affected individuals specifically, we believe that these data accurately represent the non-breeding-season movements of pink-footed shearwaters. Nevertheless, attachment durations for the suture-tape-glue method likely vary by species, researcher experience, or unknown extrinsic factors. To further investigate tagging effects, future studies involving post-breeding dispersal and tracking using this attachment method could benefit by concerted efforts to re-sight individuals and study reproductive success during following seasons.

Pink-footed shearwaters appear unique among Pacific shearwater species in that they rely exclusively on the 2 Pacific Ocean eastern boundary current upwelling systems across their entire annual cycle, in this case the southern Humboldt Current (Chile) during the breeding season and the northern Humboldt (Peru) and California currents during the non-breeding season. Sooty shearwaters breeding in southern Chile may perform a similar migration; however, this population has not been tracked and individuals breeding in New Zealand migrate to both the western and eastern north Pacific (Shaffer et al. 2006). In the Atlantic Ocean, Scopoli's shearwaters Calonectris diomedea utilize a similar strategy by migrating from Mediterranean breeding sites to either the Canary or Benguela eastern boundary currents off western Africa (Ramos et al. 2009). Pinkfooted shearwater core use was concentrated over shelf and upper slope waters in both the northern Humboldt (north-central Peru) and California currents (central Baja California, southern to central California, and central Oregon to southern Vancouver Island; Fig. 3). In the California Current, pinkfooted shearwater distribution appears to overlap latitudinally with non-breeding-season sooty shearwater habitat, although pink-footed shearwaters tend to be found farther offshore over the shelf-break and upper-slope (Briggs et al. 1987, Ainley et al. 2005, Mason et al. 2007, Adams et al. 2012, 2014).

As productivity wanes at the end of the austral summer in the southern Humboldt Current, pinkfooted shearwaters likely move north to access the more year-round, albeit variably so, productive upwelling waters of the northern Humboldt Current off Peru (Alheit \& Niquen 2004, Vargas et al. 2007). This 
area might benefit pink-footed shearwaters during the austral summer also, as individuals are known to be present there year-round (Hinojosa Saez \& Hodum 2007). However, these individuals likely are non-breeders because the northern Humboldt Current is beyond the foraging range of breeding adults foraging from Chilean colonies (Carle et al. 2019). While in the California Current during the boreal spring and summer, pink-footed shearwaters likely exploit waters with persistent seasonal upwelling and productivity off Baja California, Mexico, and central/southern California, USA. (Checkley \& Barth 2009). Shearwaters also utilized productive waters off central Oregon to northern Washington, USA, where seasonally intermittent upwelling, combined with large freshwater and nutrient inputs, typically drive increased productivity (Venegas et al. 2008, Checkley \& Barth 2009). In Chile and Peru, pinkfooted shearwaters are known to forage on and associate with sardine (Clupeidea) and anchovy (Engraulidae; Guicking et al. 2001, Jahncke et al. 1998a,b). Off central and southern California, pink-footed shearwaters have been observed foraging on squid and engraulid fishes (COSEWIC 2004). Dependence on these prey types, which are predominantly antitropical and tied to the seasonal upwelling of nutrient-rich waters (Parrish et al. 1989), may explain why pink-footed shearwaters do not utilize oligotrophic tropical waters off Central America during the nonbreeding period. The lower relative productivity, lower seasonal variability, and patchily distributed prey resources (e.g. flying fish Exocoetidae) of these systems dictate a dependence of most tropical seabirds on subsurface predators (e.g. tuna) to facilitate foraging in both the breeding and non-breeding periods (Jaquemet et al. 2004, Catry et al. 2009, Le Corre et al. 2012, Cecere et al. 2013, McDuie \& Congdon 2016). Future study of pink-footed shearwater diet could illuminate how preferred prey availability may drive small- and large-scale non-breeding movements.

Although we lacked sufficient annual sample sizes to evaluate inter-annual variability in the timing of migration and relative importance of waters off Peru versus North America, it is possible that annual variability in the strength of upwelling and productivity in the Humboldt Current could influence the proportion of birds remaining off Peru for the entire nonbreeding period and/or how long they stop there en route to the California Current off North America. For example, enhanced prey availability off Peru could cause birds to remain longer before continuing northward, or even cause a greater proportion of the population to remain there throughout the nonbreeding period (Ainley 1976). Alternatively, sufficient prey availability off Peru could provide birds the fuel needed to continue to North America after a relatively brief stopover, assuming the California Current is the desired destination. As evidenced by the one individual in our study that was diverted by a hurricane (a phenomenon documented in other seabird studies; Hass et al. 2012), meteorological conditions may also play a role in determining migratory destination. Variations in wind patterns have been hypothesized to affect the timing of trans-hemispheric migration of Cory's shearwaters in the Atlantic (Felicísimo et al. 2008), but have also been shown to be unrelated to ultimate migratory destination (Dell'Ariccia et al. 2018). In addition, colonylevel, individual-level, and sex-specific differences in migratory behavior could be important determinants of migratory routes (Catry et al. 2011, Müller et al. 2014).

Although only $28 \%$ of tagged birds ultimately spent the entire non-breeding period off Peru, this region was a migratory bottleneck for the entire migratory population (primarily in May and October when North American migrants stopped over for 1-3 wk); therefore, waters off Peru are disproportionately important to the population (even more so if non-breeding birds spend additional time there during the austral summer; Hinojosa Saez \& Hodum 2007). This bottleneck in northern South America has important conservation implications because relatively high levels of bycatch have been reported in Peruvian fisheries (Mangel et al. 2012). Based on extrapolation of capture rates from on-board observations, Mangel et al. (2012) estimated annual mortality of 500 to 1000 pink-footed shearwaters in Peruvian small-scale gill-net fisheries (Table 2). Industrial purse-seine fishing in Peru has not been studied for bycatch, although recent research indicates substantial spatial overlap during the breeding period among pink-footed shearwaters and central Chilean artisanal and industrial purse-seine fishing effort (Carle et al. 2019). These fisheries are characterized by relatively high rates of documented pink-footed shearwater bycatch (i.e. $>1500$ observed mortalities over 3 yr, Vega et al. 2018; Table 2), suggesting that significant bycatch could exist in Peruvian purseseine fisheries as well (Mangel et al. 2012). In addition, Mangel et al. (2012) estimated 1000 individuals were caught annually in central and northern Chilean small-scale gill-net, purse-seine, and longline fisheries (mostly gill-net; Table 2). Coupled with our tracking results, this evidence suggests that a 
significant portion of the global pink-footed shearwater population could be threatened year-round by fisheries interactions and associated mortality.

Bycatch rates in other important non-breedingseason areas we identified are likewise little studied, but existing evidence indicates that the risk of bycatch may be much lower off North America than off South America. For example, pink-footed shearwater bycatch has been documented in Mexican purseseine fisheries in the Gulf of California at low levels (i.e. $<10$ birds; Enriqueta Velarde unpubl. data; Table 2). Documented cases of pink-footed shearwater bycatch in US long-line and trawl fisheries are also low, with annual mortality estimated for these fisheries of $<7$ birds $\mathrm{yr}^{-1}$ (Gladics et al. 2017, Jannot et al. 2018; Table 2). Although purse-seine fisheries in Chile are a major source of pink-footed shearwater bycatch, similar purse-seine fisheries in California waters (targeting northern anchovy Engraulis mordax, Pacific sardine Sardinops sagax, Pacific mackerel Scomber japonicus, jack mackerel Trachurus symmetricus, and market squid Doryteuthis opalescens) are not monitored or observed for seabird bycatch (California Department of Fish and Wildlife 2018). Additional assessments of fisheries bycatch in countries supporting the greatest relative pinkfooted shearwater use during the non-breeding season (USA, Peru, and Mexico) could be informative and benefit conservation of the species. Whereas fisheries bycatch is considered one of the primary threats to pink-footed shearwaters at sea, additional at-sea threats may also exist to pink-footed shearwaters during their non-breeding period, such as oil spills (Hampton et al. 2003), chemical pollution (Cifuentes et al. 2003), plastic ingestion (Hutton et al. 2008), potential offshore energy development (Kelsey et al. 2018), and competition with fisheries (Cury et al. 2011).

During the non-breeding period, pink-footed shearwaters utilized the EEZ waters of 12 countries-most importantly USA, Mexico, and Peru (Table 2, Fig. 3) - each with their own specific fisheries practices, and each with different conservation laws and unique conservation listings for the species. Our results highlight the importance of international cooperation for the conservation and management of pink-footed shearwaters and similar highly migratory seabirds (see Nevins et al. 2009). The Agreement on the Conservation of Albatrosses and Petrels (ACAP) treaty provides an international framework for multinational conservation actions, though not all nations with core habitat for pink-footed shearwaters are signatories (notably, the USA are not a signatory, but Chile and Peru are). Major data gaps exist regarding fisheries interactions and bycatch of pinkfooted shearwaters in each country, especially in Peru, Ecuador, and Mexico. Chile has recently increased awareness of bycatch issues, begun to document bycatch capture rates and mortality (Vega et al. 2018), and implemented governmental action (i.e. National Plan for Conservation of pink-footed shearwater [Hinojosa Saez \& Hodum 2007], and pending fisheries national plans [e.g. SUBPESCA 2003]). The results of the present study indicate that additional data sharing, collaborative prioritization, and the pursuit of collective implementation of conservation actions among nations could benefit the pink-footed shearwater.

Acknowledgements. Research in this study was made possible with support from American Bird Conservancy, Bureau of Ocean Energy Management, communities of Isla Mocha and Islas Juan Fernández, Corporación Nacional Forestal and Servicio Agrícola y Ganadería (Chile), Environment Canada, the National Fish and Wildlife Foundation, the National Geographic Society, ProDelphinus, and the Wallis Foundation. Capture and tagging methods for the USA were approved under the USGS Animal Care and Use Committee \#WERC-2007-03 and USGS Bird Banding and Auxiliary Marking Authority permit \#22911 and \#23843. This study was authorized in Chile under No. Resolución SAG: 1090 (12-02-2015). The use of trade, product, or firm names in this publication is for descriptive purposes only and does not imply endorsement by the US Government. K. Morgan (Canadian Wildlife Service) kindly contributed knowledge and a portion of the satellite tags used in this study. Special thanks to V. López (Oikonos Ecosystem Knowledge), Jaime Herrera, and Alejandro Gajardo in Chile and to D. Mazurkiewicz, K. Schmidt, J.T. Harvey, and L. Harvey in California for field and logistical support. We thank D. Douglas for analytical support and manuscript review. J. Beck, E. Kelsey, C. Kroeger, and J. Mangel provided thoughtful feedback and revisions on portions of this manuscript.

\section{LITERATURE CITED}

ACAP (2015) Agreement on the conservation of albatrosses and petrels achievements in the first ten years 20042014. ACAP Secretariat, Hobart. www.acap.aq/all-thedocs/misc-docs/2590-achievements-in-the-first-ten-years2004-2014/file?lang=en

Adams J, MacLeod C, Suryan RM, Hyrenbach KD, Harvey JT (2012) Summer-time use of west coast US National Marine Sanctuaries by migrating sooty shearwaters (Puffinus griseus). Biol Conserv 156:105-116

Adams J, Felis JJ, Mason JW, Takekawa JY (2014) Pacific Continental Shelf Environmental Assessment (PaCSEA): aerial seabird and marine mammal surveys off northern California, Oregon, and Washington, 2011-2012. Bur Ocean Energy Manage 2014-003. Bureau of Ocean Energy Management, Washington, DC

Ainley DA (1976) The occurrence of seabirds in the coastal region of California. West Birds 7:33-68 
Ainley DG, Spear LB, Tynan CT, Barth JA, Pierce SD, Ford RG, Cowles TJ (2005) Physical and biological variables affecting seabird distributions during the upwelling season of the northern California Current. Deep Sea Res II 52:123-143

Alheit J, Niquen M (2004) Regime shifts in the Humboldt Current ecosystem. Prog Oceanogr 60:201-222

Amante C, Eakins BW (2009) ETOPO1 1 Arc-Minute Global Relief Model: procedures, data sources and analysis. NOAA Tech Memo NESDIS NGDC-24. https://repository. library.noaa.gov/view/noaa/1163/noaa_1163_DS1.pdf

ATF (Albatross Task Force) (2013) Demersal trawl report (2011-2012). BirdLife International, Santiago

Bielli A (2017) Reducing bycatch using illuminated gillnets: a brighter future for marine life. MSc thesis, University of Exeter

BirdLife International (2017) Ardenna creatopus (amended version of 2016 assessment). The IUCN Red List of Threatened Species 2017:e.T22698195A112079183. https:// dx.doi.org/10.2305/IUCN.UK.2018-2.RLTS.T22698195A 132633266.en (accessed 9 July 2018)

Block BA, Jonsen ID, Jorgensen SJ, Winship AJ and others (2011) Tracking apex marine predator movements in a dynamic ocean. Nature 475:86-90

Briggs KT, Tyler WB, Lewis DB, Carlson DR (1987) Bird communities at sea off California: 1975 to 1983. Cooper Ornithological Society, No. 598.2. BIR, Lawrence KS

Brooke M (2004) Albatrosses and petrels across the world. Oxford University Press, Oxford

Calenge C (2006) The package 'adehabitat' for the R software: a tool for the analysis of space and habitat use by animals. Ecol Modell 197:516-519

California Department of Fish and Wildlife (2018) Pelagic fisheries and ecosystems program. www.wildlife.ca. gov/Conservation/Marine/Pelagic\#52132542-overview (accessed 31 October 2018)

*arey MJ, Phillips RA, Silk JR, Shaffer SA (2014) Transequatorial migration of short-tailed shearwaters revealed by geolocators. Emu 114:352-359

Carle RD, Beck JN, Colodro V, Hodum P (2016) Effects of cattle exclusion on the vegetation at a pink-footed shearwater (Ardenna creatopus) colony on Robinson Crusoe Island, Chile. Rev Chilena Ornitol 22:184-193

Carle RD, Felis JJ, Vega R, Beck J and others (2019) Overlap of pink-footed shearwaters and central Chilean purseseine fisheries: implications for bycatch risk. Condor; https://dx.doi.org/10.1093/condor/duz026

* Catry T, Ramos JA, Le Corre M, Phillips RA (2009) Movements, at-sea distribution and behaviour of a tropical pelagic seabird: the wedge-tailed shearwater in the western Indian Ocean. Mar Ecol Prog Ser 391: 231-242

Catry P, Dias MP, Phillips RA, Granadeiro JP (2011) Different means to the same end: long-distance migrant seabirds from two colonies differ in behaviour, despite common wintering grounds. PLOS ONE 6:e26079

Cecere JG, Calabrese L, Rocamora G, Catoni C (2013) Movement patterns and habitat selection of wedgetailed shearwaters (Puffinus pacificus) breeding at Aride Island, Seychelles. Waterbirds 36:432-438

* Checkley DM Jr, Barth JA (2009) Patterns and processes in the California Current System. Prog Oceanogr 83:49-64

Cifuentes JM, Becker PH, Sommer U, Pacheco P, Schlatter R (2003) Seabird eggs as bioindicators of chemical contamination in Chile. Environ Pollut 126:123-137
COSEWIC (2004) COSEWIC assessment and status report on the pink-footed shearwater Puffinus creatopus in Canada. Committee on the Status of Endangered Wildlife in Canada, Ottawa

Costa DP, Robinson PW, Arnould JPY, Harrison AL and others (2010) Accuracy of ARGOS locations of pinnipeds at sea estimated using Fastloc GPS. PLOS ONE 5:e8677

Coyne MS, Godley BJ (2005) Satellite Tracking and Analysis Tool (STAT): an integrated system for archiving, analyzing and mapping animal tracking data. Mar Ecol Prog Ser 301:1-7

C Croxall JP, Butchart SH, Lascelles B, Stattersfield AJ, Sullivan B, Symes A, Taylor P (2012) Seabird conservation status, threats and priority actions: a global assessment. Bird Conserv Int 22:1-34

Cury PM, Boyd IL, Bonhommeau S, Anker-Nilssen T and others (2011) Global seabird response to forage fish depletion - one-third for the birds. Science 334:1703-1706

Dávila Pérez C, Velasquez Jofre P, Siguenza R (2009) Diagnostico de captura incidental de aves marina en el Pacifico de Guatemala, Centro America. Informe Final. Unpublished report to Pacific Seabird Group, Corvalis, OR. www.pacificseabirdgroup.org/GrantReports/Siguenza DeMicheo.FinalReport.2010.pdf

*Dell'Ariccia G, Benhamou S, Dias MP, Granadeiro JP, Sudre J, Catry P, Bonadonna F (2018) Flexible migratory choices of Cory's shearwaters are not driven by shifts in prevailing air currents. Sci Rep 8:3376

* Dias MP, Granadeiro JP, Catry P (2013) Individual variability in the migratory path and stopovers of a long-distance pelagic migrant. Anim Behav 86:359-364

*Douglas DC, Weinzierl R, Davidson SC, Kays R, Wikelski M, Bohrer G (2012) Moderating Argos location errors in animal tracking data. Methods Ecol Evol 3:999-1007

Einoder LD, Goldsworthy SD (2005) Foraging flights of short-tailed shearwaters (Puffinus tenuirostris) from Althorpe Island: assessing their use of neritic waters. Trans R Soc S Aust 129:209-216

Environment Canada (2008) Recovery strategy for the shorttailed albatross (Phoebastria albatrus) and the pinkfooted shearwater (Puffinus creatopus) in Canada. Species at Risk Act Recovery Strategy Series, Environment Canada, Ottawa

Felicísimo ÁM, Muñoz J, González-Solis J (2008) Ocean surface winds drive dynamics of transoceanic aerial movements. PLOS ONE 3:e2928

Freitas C, Lydersen C, Fedak MA, Kovacs KM (2008) A simple new algorithm to filter marine mammal Argos locations. Mar Mamm Sci 24:315-325

KGladics AJ, Melvin EF, Suryan RM, Good TP, Jannot JE, Guy TJ (2017) Fishery-specific solutions to seabird bycatch in the US West Coast sablefish fishery. Fish Res 196:85-95

*González-Solís J, Croxall JP, Oro D, Ruiz X (2007) Transequatorial migration and mixing in the wintering areas of a pelagic seabird. Front Ecol Environ 5:297-301

Guicking D, Mickstein S, Schlatter RP (1999) Estado de la poblacion de fardela blanca (Puffinus creatopus) en Isla Mocha, Chile. Bol Chil Ornitol 6:35-38

* Guicking D, Ristow D, Becker PH, Schlatter R, Berthold P, Querner U (2001) Satelling tracking of pink-footed shearwater in Chile. Waterbirds 24:8-15

Guicking D, Fiedler W, Leuther C, Schlatter R, Becker PH (2004) Morphometrics of the pink-footed shearwater (Puffinus creatopus): influence of sex and breeding site. J Ornithol 145:64-68 
Guilford T, Meade J, Willis J, Phillips RA and others (2009) Migration and stopover in a small pelagic seabird, the Manx shearwater Puffinus puffinus: insights from machine learning. Proc Biol Sci 276:1215-1223

Hampton S, Ford RG, Carter HR, Abraham C, Humple D (2003) Chronic oiling and seabird mortality from the sunken vessel SS Jacob Luckenbach in Central California. Mar Ornithol 31:35-41

Hass T, Hyman J, Semmens BX (2012) Climate change, heightened hurricane activity, and extinction risk for an endangered tropical seabird, the black-capped petrel Pterodroma hasitata. Mar Ecol Prog Ser 454:251-261

Hedd A, Montevecchi WA, Otley H, Phillips RA, Fifield DA (2012) Trans-equatorial migration and habitat use by sooty shearwaters Puffinus griseus from the South Atlantic during the nonbreeding season. Mar Ecol Prog Ser 449:277-290

Hinojosa Saez A, Hodum P (eds) (2007) Plan nacional para la conservacion de la fardela de vientre blanco Puffinus creatopus Coues, 1864 en Chile. Corporación Nacional Forestal \& Comisión Nacional del Medio Ambiente, Santiago

Hutton I, Carlile N, Priddel D (2008) Plastic ingestion by flesh-footed shearwaters, Puffinus carneipes, and wedgetailed shearwaters, Puffinus pacificus. Pap Proc R Soc Tasman 142:67-72

Jahncke J, Perez J, Garcia-Godos A (1998a) Abundancia relativa y distribucion de aves marinas frente a la costa Peruana y su relacion con la anchoveta. Crucero BIC Humboldt 9803-05 de Tumbes a Tacna. Inf Inst Mar Peru 135:153-162

Jahncke J, Ayala L, Mendoza C (1998b) Abundancia relativa y distribucion de aves marinas frente a la costa Peruana y su relacion con la abundancia de anchoveta. Crucero BIC Humboldt 9808-09, de Piura a Lima. Inf Inst Mar Peru 141:82-95

Jannot JE, Somers KA, Tuttle V, McVeigh J, Good TP (2018) Seabird mortality in U.S. west coast groundfish fisheries, 2002-16. US Department of Commerce, NOAA Tech Memo NMFS-NWFSC-146. https://doi.org/10.25923/ qeyc-0r73

Jaquemet S, Le Corre M, Weimerskirch H (2004) Seabird community structure in a coastal tropical environment: importance of natural factors and fish aggregating devices (FADs). Mar Ecol Prog Ser 268:281-292

Johnson DH, Shaffer TL, Gould PJ (1993) Incidental catch of marine birds in the North Pacific high seas driftnet fisheries in 1990. Bulletin INPFC 53:473-483

Johnson DS, London JM, Lea MA, Durban JW (2008) Continuous time correlated random walk model for animal telemetry data. Ecology 89:1208-1215

Kelsey EC, Felis JJ, Czapanskiy M, Pereksta DM, Adams J (2018) Collision and displacement vulnerability to offshore wind energy infrastructure among marine birds of the Pacific outer continental shelf. J Environ Manage 227:229-247

Klomp NI, Schultz MA (2000) Short-tailed shearwaters breeding in Australia forage in Antarctic waters. Mar Ecol Prog Ser 194:307-310

Le Boeuf BJ, Crocker DE, Costa DP, Blackwell SB, Webb PM, Houser DS (2000) Foraging ecology of northern elephant seals. Ecol Monogr 70:353-382

Le Corre M, Jaeger A, Pinet P, Kappes MA and others (2012) Tracking seabirds to identify potential Marine Protected Areas in the tropical western Indian Ocean. Biol Conserv 156:83-93
Macleod CJ, Adams J, Lyver P (2008) At-sea distribution of satellite-tracked grey-faced petrels, Pterodroma macroptera gouldi, captured on the Ruamaahua (Aldermen) Islands, New Zealand. Pap Proc R Soc Tasman 142:73-88

Mallory ML, Gilbert CD (2008) Leg-loop harness design for attaching external transmitters to seabirds. Mar Ornithol 36:183-188

Mangel JC (2012) Interactions of Peruvian small scale fisheries with threatened marine vertebrate species. $\mathrm{PhD}$ dissertation, University of Exeter

Mangel JC, Adams J, Alfaro-Shigueto J, Hodum P and others (2012) Conservation implications of pink-footed shearwater movements and fishery interactions assessed using multiple methods. Unpublished report to American Bird Conservancy, Washington, DC. http://oikonos.org/papers/ SBWG5_Doc_06_Mangel_et_al._pink-footed_shearwater_ E_s_f.pdf

Mason JW, McChesney GJ, McIver WR, Carter HR and others (2007) At-sea distribution and abundance of seabirds off southern California: a 20-year comparison. Studies in Avian Biology, Vol 33. Cooper Ornithological Society, Camarillo, CA

McDuie F, Congdon BC (2016) Trans-equatorial migration and non-breeding habitat of tropical shearwaters: implications for modelling pelagic Important Bird Areas. Mar Ecol Prog Ser 550:219-234

兴Müller MS, Massa B, Phillips RA, Dell'omo G (2014) Individual consistency and sex differences in migration strategies of Scopoli's shearwaters Calonectris diomedea despite year differences. Curr Zool 60:631-641

National Hurricane Center (2018) National Hurricane Center data archive. www.nhc.noaa.gov (accessed September 2018)

*Nevins HM, Adams J, Moller H, Newman J, Hester M, Hyrenbach KD (2009) International and cross cultural management in conservation of migratory species. J R Soc N Z 39:183-185

Newman SH, Takekawa JY, Whitworth DL, Burkett EE (1999) Subcutaneous anchor attachment increases retention of radio transmitters on Xantus' and marbled murrelets. J Field Ornithol 70:520-534

Ogi H, Yatsu A, Hatanaka H, Nitta A (1993) The mortality of seabirds by driftnet fisheries in the North Pacific. Bull INPFC 53:499-518

*Parrish RH, Serra R, Grant WS (1989) The monotypic sardines, Sardina and Sardinops: their taxonomy, distribution, stock structure, and zoogeography. Can J Fish Aquat Sci 46:2019-2036

*Powers KD, Wiley DN, Allyn AJ, Welch LJ, Ronconi RA (2017) Movements and foraging habitats of great shearwaters Puffinus gravis in the Gulf of Maine. Mar Ecol Prog Ser 574:211-226

R Core Team (2017) R: a language and environment for statistical computing. R Foundation for Statistical Computing, Vienna. www.r-project.org

Ramos R, González-Solís J, Ruiz X (2009) Linking isotopic and migratory patterns in a pelagic seabird. Oecologia 160:97-105

* Reid TA, Ronconi RA, Cuthbert RJ, Ryan PG (2014) The summer foraging ranges of adult spectacled petrels Procellaria conspicillata. Antarct Sci 26:23-32

* Ristow D, Berthold P, Hashmi D, Querner U (2000) Satellite tracking of Cory's shearwater migration. Condor 102: 696-699 
Ronconi RA, Schoombie S, Westgate AJ, Wong SN, Koopman HN, Ryan PG (2018) Effects of age, sex, colony and breeding phase on marine space use by great shearwaters Ardenna gravis in the South Atlantic. Mar Biol 165:58

Shaffer SA, Tremblay Y, Weimerskirch H, Scott D and others (2006) Migratory shearwaters integrate oceanic resources across the Pacific Ocean in an endless summer. Proc Natl Acad Sci USA 103:12799-12802

Söhle IS, Moller H, Fletcher D, Robertson CJ (2000) Telemetry reduces colony attendance by sooty shearwaters (Puffinus griseus). N Z J Zool 27:357-365

Suazo CG, Cabezas LA, Moreno CA, Arata JA and others (2014) Seabird bycatch in Chile: a synthesis of its impacts, and a review of strategies to contribute to the reduction of a global phenomenon. Pac Seabirds 41: $1-12$

SUBPESCA (2003) Plan de acción nacional de Chile para mitigar efectos de la pesca de palangre sobre aves marinas (PAN-AM). FIP 2003-21: informe final. Subsecretaria de Pesca, Valparaíso. www.subpesca.cl/fipa/613/articles89028_informe_final.pdf

Vargas G, Pantoja S, Rutllant JA, Lange CB, Ortlieb L (2007) Enhancement of coastal upwelling and interdecadal ENSO like variability in the Peru Chile Current since late 19th century. Geophys Res Lett 34:L13607

Editorial responsibility: Rory Wilson,

Swansea, UK
Vega R, Ossa L, Suárez B, González A and others (2018) Informe Final-Convenio de Desempeño 2017. Programa de observadores científicos 2017-2018. Programa de investigación del descarte y captura de pesca incidental en pesquerías pelágicas. Programa de monitoreo y evaluación de los planes de redución del descarte y de la pesca incidental 2017-2018. Instituto de Fomento Pesquero, Valparaíso

*Venegas RM, Strub PT, Beier E, Letelier R and others (2008) Satellite derived variability in chlorophyll, wind stress, sea surface height, and temperature in the northern California Current System. J Geophys Res C Oceans 113:C3

Wilson RP, Pütz K, Peters G, Culik B, Scolaro JA, Charrassin JB, Ropert-Coudert Y (1997) Long-term attachment of transmitting and recording devices to penguins and other seabirds. Wildl Soc Bull 25:101-106

* Witt MJ, Åkesson S, Broderick AC, Coyne MS and others (2010) Assessing accuracy and utility of satellite-tracking data using Argos-linked Fastloc-GPS. Anim Behav 80: 571-581

炎Worton B (1989) Kernel methods for estimating the utilization distribution in home-range studies. Ecology 70 : 164-168

Korio P (2009) Marine protected areas, spatial scales, and governance: implications for the conservation of breeding seabirds. Conserv Lett 2:171-178

Submitted: December 7, 2018; Accepted: June 7, 2019

Proofs received from author(s): July 30, 2019 